\title{
Nominations Accepted for the 2018 APSA Awards
}

S ubmit your nominations for the APSA dissertation, book, paper and article, and career awards, which will be presented at the 2018 Annual Meeting in Boston, Massachusetts. For more information, visit www.apsanet.org/awards. The 2018 awards are listed below.

\section{GOODNOW AWARD}

The Frank J. Goodnow Award is made for distinguished service to the profession and the American Political Science Association, not necessarily a career of scholarship. This service may be by individuals, groups, or public and private organizations who have played a role in the development of the political science profession and the building of the association. Nominations are due by February 20, 2018.

\section{CAREER AWARDS}

Bestowed for significant achievements related to political science. Nominations are due by February 20, 2018.

\section{APSA Distinguished Teaching Award}

To honor outstanding contributions to undergraduate and/or graduate teaching of political science at two- and four-year institutions. The award recognizes contributions that have made a significant impact on the manner in which political science is taught or individual career contributions.

\section{John Gaus Distinguished Award and Lectureship}

Honors the recipient's lifetime of exemplary scholarship in the joint tradition of political science and public administration.

\section{Hubert H. Humphrey Award}

In recognition of notable public service by a political scientist.

\section{Benjamin E. Lippincott Award}

Recognizes a work of exceptional quality by a living political theorist that is still considered significant after a time span of at least 15 years since the original date of publication.

\section{James Madison Award and Lectureship}

For an American political scientist who has made a distinguished scholarly contribution to political science.

\section{Carey McWilliams Award}

Recognizes a major journalistic contribution to our understanding of politics.

\section{Charles E. Merriam Award}

Awarded biennially to recognize a person whose published work and career represent a significant contribution to the art of government through the application of social science research.

\section{Hanes Walton, Jr. Award}

For a political scientist whose lifetime of distinguished scholarship has made significant contributions to our understanding of racial and ethnic politics and illuminates the conditions under which diversity and intergroup tolerance thrive in democratic societies.

\section{DISSERTATION AWARDS}

Departments are invited to submit nominations for dissertations that have been completed in the past two academic years. Nominations are due by February 20, 2018.

\section{Gabriel A. Almond Award}

In the field of comparative politics.

\section{William Anderson Award}

In the field of federalism or intergovernmental relations, state, or local politics.

\section{Edward S. Corwin Award}

In the field of public law.

\section{Harold D. Lasswell Award}

In the field of public policy.

\section{Merze Tate Award}

In the field of international relations, law, and politics.

\section{E.E. Schattschneider Award}

In the field of American government.

\section{Leo Strauss Award}

In the field of political philosophy.

Leonard D. White

In the field of public administration.

\section{BOOK AWARDS}

Books published in 2017 may be nominated by individuals or publishers. The deadline for nominations is February 20, 2018.

\section{Ralph J. Bunche Award}

For the best scholarly work in political science that explores the phenomenon of ethnic and cultural pluralism.

\section{Robert A. Dahl Award}

Awarded to an untenured scholar who has produced scholarship of the highest quality on the subject of democracy, including books, papers, and articles.

\section{Theodore J. Lowi Award}

For the best first book in any field of political science, showing promise of having a substantive impact on the overall discipline, regardless of method, specific focus of inquiry or approach to subject.

\section{Gladys M. Kammerer Award}

For the best political science publication in the field of US national policy.

\section{Victoria Schuck Award}

For the best book published on women and politics.

\section{Woodrow Wilson Foundation Award}

For the best book published in the United States in the field of government, politics, or international affairs.

\section{PAPER AND ARTICLE AWARDS}

Nominations are due February 20, 2018.

\section{Franklin L. Burdette/Pi Sigma Alpha} Award

For the best paper presented at the previous Annual Meeting.

\section{Robert A. Dahl Award}

For an untenured scholar who has produced scholarship of the highest quality on the subject of democracy, including books, papers, and articles.

\section{Heinz Eulau Award}

For the best articles published in the American Political Science Review and Perspectives on Politics during the previous year. 